Article

\title{
Smart Agricultural Futures Market: Blockchain Technology as a Trust Enabler between Smallholder Farmers and Buyers
}

\author{
Malni Kumarathunga *, Rodrigo N. Calheiros (D) and Athula Ginige (D) \\ School of Computing, Data, and Mathematical Sciences, Western Sydney University, \\ Parramatta, NSW 2150, Australia; r.calheiros@westernsydney.edu.au (R.N.C.); \\ a.ginige@westernsydney.edu.au (A.G.) \\ * Correspondence: m.kumarathunga@westernsydney.edu.au
}

\begin{abstract}
Smallholder farmers produce over 70\% of the world's food needs. Yet, the socioeconomic conditions of the smallholder farmers are substandard. One of the primary reasons for this unpropitious situation is that they generate modest income by selling their harvest due to the lack of trusted buyers and organized markets. This research explores how technology can enable the trust to reduce transaction-related risks, empowering unknown parties to transact. Blockchain technology has the potential of mitigating transaction-related risks and promoting trust with a tamper-proof history of transactions and automatic execution of smart contracts. Based on blockchain technology to promote trust, this research has discovered a novel approach for smallholder farmers to conduct exchanges by generating social capital as an individual and using that social capital as collateral for financial exchanges when establishing contracts. This approach empowers farmers to trade smart futures contracts on behalf of the expected harvest at a better rate to receive some cash in advance to be used in the cultivation process to produce a high-quality harvest that attracts better rates. It also enables them to perform aggregated marketing with enhanced market linkages that, in turn, assist in increasing margins made by the farmer.
\end{abstract}

Keywords: trust; farmer; risks; futures market; social capital; blockchain

Blockchain Technology as a Trust

Enabler between Smallholder

Farmers and Buyers. Sustainability

2022, 14, 2916. https://doi.org/

$10.3390 /$ su14052916

Academic Editors: Rainer Lasch

and Jacob Lohmer

Received: 31 December 2021

Accepted: 28 February 2022

Published: 2 March 2022

Publisher's Note: MDPI stays neutral with regard to jurisdictional claims in published maps and institutional affiliations.

Copyright: (๑) 2022 by the authors Licensee MDPI, Basel, Switzerland. This article is an open access article distributed under the terms and conditions of the Creative Commons Attribution (CC BY) license (https:// creativecommons.org/licenses/by/ $4.0 /)$.

\section{Introduction}

Smallholder farmers produce over $70 \%$ of the world's food needs [1], yet, the socioeconomic conditions of the smallholder farmers are substandard. They are a part of $75 \%$ of the world's poorest people who live in developing economies [2], but receive only onethird to one-half of the final price for fruits and vegetables they produce [3-5]. Although there is a possibility of obtaining higher prices in distance markets, farmers often choose intermediaries due to the lack of transport and storage facilities [6,7] and the inability to compete with dominating traders [7]. The intermediaries get higher profits by procuring harvest at low prices and selling at higher prices at distance markets. After conducting interviews among smallholder farmers in Sri Lanka, a developing country in the South Asian region, we discovered that farmers choose known brokers with pre-established trust to sell their harvest in order to receive the money within two or three weeks [8]; however, the rates provided by these brokers are low. Farmers sell their harvest to unknown brokers only if they receive cash on the spot due to the risk of not getting paid. This situation implies that minimizing the risk of not being paid by establishing trust between farmers and unknown brokers has the potential of enabling farmers to choose any broker with competitive prices without relying on known brokers. We concluded that their selling relationships predominantly depend on the pre-established trust where risk is minimal while the returns are low [8].

According to Sako, a smooth trading relationship requires both contractual and competence trust. While contractual trust ensures the promises are kept, competence trust relies 
on the trading partner's capability to carry out the task [9]. Records of previous successfully executed contracts can be used to build both contractual and competence trust with a new trading partner. Blockchain technology is an exemplary mechanism to implement contractual and competence trust with smart contracts based on an untamperable history of transactions. A tamper-proof history has the capability of establishing a network of community relationships that facilitate trust, motivating purposeful action, known as social capital [10].

In addition, the futures contract, an agreement to buy or sell an asset at a particular time in the future for a specific price [11], has evolved as a risk management tool when there is a risk of price uncertainty [12]. Although futures markets are recognized as an effective strategy for farmers to reduce the price risk [13], farmers' participation in the futures market is low [14], especially in developing countries.

Social capital and trust can be extended beyond known trading entities by creating commodity exchanges such as futures contracts with formal monitoring and enforcement [15]. Thus, in this research, we explore how a blockchain technology-based system can be created for smallholder farmers to generate social capital and then use that social capital as collateral for financial exchanges, empowering the farmers to establish trustworthy trading relationships with any buyer having a good transaction history. Based on that, we present the conceptual design of a novel futures market platform, the Smart Agricultural Futures Market (SAFM), that can enable farmers to sell their expected harvest to any buyer as smart futures contracts. This design uses blockchain for monitoring, smart contracts for enforcements, and uses social capital as collateral. Since researchers have demonstrated that collective marketing has the potential of increasing farmers' margins [16-18], we enrich the trading relationships in the futures market platform with Many-one-Many (MoM) market linkages. Thus, the platform enables farmers to aggregate their harvest community-wise, inducing high bargaining power, leading to better farm-gate prices with improved access to bigger markets. We further enable farmers to receive some money in advance, alleviating financial burdens and enabling farmers to produce high-quality harvest by purchasing quality Agri inputs at the right time in the right amounts to attract higher rates.

The proposed market platform incorporates four features to increase farmers' margins.

1. Empowering farmers to establish trustworthy relationships with a buyer who offers higher prices, reducing transaction-related risks.

2. Enabling farmers to sell their expected harvest using futures contracts, mitigating future price uncertainties, using social capital as collateral.

3. Establishing MoM market linkages, providing high bargaining power to farmers, enabling them to access bigger markets, leading to better prices.

4. Facilitating farmers to receive some cash in advance to be used in the cultivation process to produce a high-quality harvest that helps to attract higher rates, mitigating financial risks.

Finally, in this paper, we present the novel approach of establishing social capital by enabling trust progressively between unknown parties based on blockchain technology, facilitating them to engage in three different exchange patterns: deliver material to receive money on the spot, deliver material early to receive money later and to receive money early and deliver material later, in a futures market platform. This proposed approach is applicable to any domain, not only in the Agri domain. The established social capital has the potential of engendering new forms of exchanges, such as empowering farmers to establish contracts with agri-inputs suppliers to pay later once the harvest is sold or to pay in installments, alleviating production-related risks. While the market platform empowers farmers to generate better revenue from their harvest, it induces future possibilities of empowering farmers to purchase insurance policies against production losses and aggregating input requirements to purchase agri-inputs at low cost, reducing production risks and increasing margins further. This research is carried out in accordance with Design Science Research (DSR) methodology [19]. After thoroughly reviewing the conceptual design, the prototype will be validated as part of an ongoing project to empower farmers. 
Hence, this paper is organized as follows. Section 2 reviews the literature on the building blocks that are required for creating a Smart Agricultural Futures Market (SAFM), including social capital, community trust, and blockchain technology. Section 3 describes the SAFM, followed by Section 4 , in which we include the discussion. Section 5 consists of the conclusion.

\section{Background: The Building Blocks}

\subsection{Trust}

Trust is undeniably important for human beings to survive as a community since it enables exchanges. Mayer et al. [20] define trust as "willingness of a party to be vulnerable to the actions of another party based on the expectation that the other will perform a particular action important to the trustor, irrespective of the ability to monitor or control that other party" [20]. The trustor is the person who places him or herself in a vulnerable position under insecurity, and the trustee is the person whom the trust is placed and who has the advantage of the trustor's vulnerability [21]. Tan and Theon [22] declare that transaction trust in electronic commerce depends on the trust placed in the counterparty (party trust) who engages in the transaction, trust in the control mechanism (control trust), potential gain, and the risks associated with the transaction. The control mechanism defines the procedures and protocols that monitor and control the successful performance of a transaction [22].

\subsection{Community Trust and Social Capital}

Communities are built on trust [23], most preferably the "generalized trust" that is based on voluntary regulations of social relations between unknown individuals. These individuals perform actions without knowing the reciprocal actions of others, believing that positive communal relationship development will reward their engagement in good faith [24]. The reward emerges as a specific social value to an individual, apparently the social capital [10]. More the social capital is used, trust, association, and civic engagement are expanded, engendering collective wellbeing of the community [25].

In the time of the internet era, communities can be formed as virtual communities. Building online communities enables effective market communication that generates multiple benefits, improving target marketing and brand awareness [26]. Brand awareness stimulates the desire and actual participation of individuals in group activities. The brand emphasizes the similarities among community members, leading to a more robust social identity for individuals [27]. A stronger social identity in a specific community inspires individuals to conform to the community norms, modifying their behaviors per group members' expectations [28]. Mutual identification engenders community trust, motivating individual members to contribute to community welfare [29].

\subsection{Blockchain Technology}

Blockchain is a synchronized and shared distributed ledger among computers in a peer-to-peer network where each computer has its own set of records called blocks [19]. Each block consists of a group of transactions, the cryptographic hash of the previous block, and a nonce. A nonce is a random number used for verifying the hash [20]. Since each block has the previous block's hash, they are linked through the hash pointer. The blocks are timestamped to record the exact creation time of the record [19]. These linked blocks create a chain of blocks, thus the name Blockchain [21].

Each node in a blockchain network maintains a historical record of each transaction, enabling it to access information at any point, eliminating the need for a central authority [22]. The network of users validates the transactions through a decentralized consensus mechanism without a trusted third-party intermediary and adds them to create a block [23]. Once a transaction is added to a block, altering it becomes infeasible since it requires changing all preceding blocks. Although an alteration becomes successful in a node, that process has to be repeated in all participating nodes that require a large amount of computational 
power. Thus, blockchain is featured with a tamper-proof characteristic and is secure by its design [19]. It solves the long-standing double spending problem of using the same resource in different processes in multiple instances [19]. Some of the core technologies in blockchain are asymmetric encryption, P2P, distributed ledger, consensus mechanism, and smart contracts [30].

\subsubsection{Smart Contracts}

The concept of smart contracts, introduced by Szabo in 1997 [31], has gained popularity with the emergence of blockchain. A smart contract is a self-executable, self-enforceable, selfverifiable, and self-constraint code deployed and executed on a blockchain platform [32]. The code in a smart contract can be programmed to enable the execution and enforcement of the pre-defined terms of an agreement written between untrusted parties [33]. It has the capacity to eliminate the need for trusted third-party intermediaries such as lawyers and banks to enforce the terms of an agreement, leading to reduced transaction costs. Automating tasks without the need for a middleman ensue in reduced time [34].

Since the records in a blockchain are immutable and tamper-proof [35], a smart contract deployed on the blockchain is infeasible to alter [33]. The automatic execution of pre-defined contract terms enables transferring the digital assets, ensuring the contract terms are executed without any deviation. Thus, the smart contract in a blockchain has the potential of protecting from the vagaries of human discretion and breaching of contracts [36].

\subsubsection{How Blockchain Technology Enables Trust in Digital Environments}

The fundamental properties of blockchain are immutability, integrity, transparency, fair access, and non-repudiation [37]. Non-repudiation means that participants are in an undeniable state about the transactions they performed and the behavior of that transaction. For example, when A sends a message to B, A cannot repudiate that behavior, ad B cannot deny receiving that message [38]. The inability of each party to deny their behavior in the digital environment enables unknown parties to commit exchanges, facilitating both party trust and control trust.

Blockchain supports non-repudiation through digital signature schemes [38]. Digital signature schemes also provide message authentication and data integrity [39]. While the message authentication feature confirms the particular sender created the message, the data integrity feature assures that message is not altered during the transit [40].

In addition, immutability and transparency contribute to the reliability of the information recorded in the blockchain [41]. Information reliability is when the records can be trusted as a full and accurate representation of the transactions [42]. Reliable information influence trust automation [43]. Thus, when a contract is established in blockchain in the form of smart contracts, the parties can be assured the contracts will not be altered, and they can rely on the information embedded in the smart contract, leading to trust in the system (control trust). Moreover, the automatic execution of smart contracts results in enhancing this trust.

When a virtual community is created in a blockchain platform, the transactions between the community members are recorded in the blockchain in a tamper-proof manner. Since blockchain supports non-repudiation [38], each transaction recorded in the blockchain contributes to building the social capital for an individual. That social capital can be signified using a rank. The rank is calculated using the successful transactions performed against the total transactions engaged by a particular individual and can be used as a trust indicator for him.

Aggregating the ranks of all members in the community to compute the average rank can be assigned to the community as well, providing a trust indicator for the community, enabling individuals outside the community to commit exchanges with community members. The community rank can emerge as the community brand reputation to the outside world. 
We apply these notions in the Agri domain, enabling trust among farmers and buyers, engendering transaction trust. It motivates both parties to commit exchanges, mitigating risks related to the transaction. However, there should be additional strategies to minimize agriculture-related risks to achieve the optimal benefit since risks are inherent in the agriculture sector.

\subsection{Agriculture-Related Risks}

While agriculture-related risks have been classified into five types: production, market, institution, personal, and financial [44], Thompson et al. [45] claim that production, financial, and market risks are more conspicuous than personal and institutional risks [45]. Farm-level risk analysis reveals that farmers consider price and yield variability the crucial sources of risks [46]. Some other farmers believe that risks associated with price uncertainty are more significant [12,47]. Wheat, corn, soybean, tobacco, and cotton farmers from the United States acknowledge that price and yield risk are the primary sources of risks [48]. While Dutch livestock farmers consider price and production risks as dominant risk sources [49], milk farmers in Turkey and Slovakia regard that one of the most critical risk sources is price volatility $[50,51]$.

Due to the impact of price volatility, farmers receive only a third to half of the final price of vegetables and fruits [3-5]. Rural farmers often sell their harvest to middlemen due to farmers' lack of storage and transport facilities and inability to compete with dominating prominent traders and auction-based sales in distant markets. Intermediaries procure harvest at the lowest possible prices to generate higher profits [7]. Due to the absence of apparent competition among these commission agents, farmers have less bargaining power when selling their harvest [52]. Moreover, for the farmers to obtain better rates, they should produce a high-quality harvest that requires access to finance early in the cultivation process to purchase the right amounts of Agri inputs at the correct time [53].

With the absence of apparent financial constraints, there is evidence that farmers' agricultural output can be increased by $26 \%$ [54]. The rise of usage in fertilizer, biocides, improved seeds, and mechanization, and the hike in prices over the recent decades have led to escalated credit requirements [55]. Due to the lack of finance, farmers refrain from cultivating high-value crops that have the potential of generating higher profits [56]. They encounter financial difficulties in covering the costs of transportation and accessing information on the market conditions [6]. Although microfinance has evolved as a prime institutional source to provide financial facilities to such people [57], it has adversely affected these underprivileged farmers, as tabulated in Table 1.

Table 1. Adverse outcomes of microfinance.

\begin{tabular}{|c|c|c|}
\hline Reason & Outcome & Source \\
\hline $\begin{array}{l}\text { Inability to fulfill the financial needs from } \\
\qquad \text { a single loan }\end{array}$ & $\begin{array}{c}\text { obtain loans from several microfinance } \\
\text { institutions (MFIs) or borrow a new loan to pay } \\
\text { the previous loan, leading to a spiraling level of } \\
\text { indebtedness }\end{array}$ & [58] \\
\hline $\begin{array}{l}\text { sell their assets or use other types of } \\
\text { earnings to pay the loans back }\end{array}$ & $\begin{array}{l}\text { Reduce their ability to fulfill vital consumption } \\
\text { requirements }\end{array}$ & {$[58,59]$} \\
\hline $\begin{array}{l}\text { microfinance institutions target prompt } \\
\text { repayments }\end{array}$ & $\begin{array}{l}\text { use aggressive loan recovery tactics using a field } \\
\text { worker from the same community } \\
\text { deteriorated social relations with other families } \\
\text { in the community }\end{array}$ & [58] \\
\hline $\begin{array}{l}\text { microfinance is associated with higher } \\
\text { transaction costs and interest rates }\end{array}$ & $\begin{array}{c}\text { the loan plus interest causes severe indebtedness } \\
\text { lead to tragic incidents such as suicides } \\
\text { organ trafficking } \\
\text { selling income-generating assets such as } \\
\text { farmlands and livestock, and sending the } \\
\text { children to work }\end{array}$ & $\begin{array}{c}{[60-63]} \\
{[64]} \\
{[65]}\end{array}$ \\
\hline
\end{tabular}


Thus, mitigating financial risks and market risks is crucial for smallholder farmers to generate better income through quality harvest. Futures contracts are used as risk management tools when the price is a source of risk [12,13]. Thus, we integrate all these building blocks to build a smart futures market for farmers.

While the proposed futures market mitigates transaction-related risks, leading to minimized market risks, we propose a novel approach where the farmers are facilitated to receive some money for a portion of the expected harvest while crops are still growing, alleviating financial risks and microfinance issues as well. Thus, the credit availability enables farmers to purchase better Agri input in the right amounts to be applied at the right time to produce a quality harvest. Quality harvest attracts higher prices, increasing farmers' profit margins further.

\subsection{Related Works}

Due to the popularity of blockchain technology achieved in recent years, researchers tend to apply it to many real-world problems, including the agriculture industry. However, literature related to blockchain-based agricultural markets can be found only very recently.

In 2020, Liao et al. presented BeIMP, an integrated market platform for contract production, targeting small-scale farmers for contract production and transactions. Similar to SAFM, BeIMP also allows farmers to establish a contract and buyers to re-sell the order, diversifying risks. However, it does not allow farmers to aggregate their produce to achieve better bargaining positions. While SAFM enables farmers to receive some money directly from the buyer without obtaining any loan, BeIMP enables farmers to acquire financing from financial institutions using the formed order. It attempts to introduce an insurance scheme to share risks in future deployments as well [66].

A peer-to-peer decentralized agricultural platform named KHET that eliminates all intermediaries between farmers, landlords, and the market was presented by Paul et al. in 2019. All the Agri supply chain stakeholders, from landlords, seed companies, fertilizer companies, and markets, are included in KHET. The farmers are allowed to enter into agreements with each stakeholder to receive the land and Agri inputs without cash at a higher rate. Once the harvest is sold in the market, stakeholders are to be paid first while the balance is transferred to the farmer's Ethereum account. As in BeIMP, KHET also expects to integrate insurance companies as a stakeholder in the future. However, KHET has not focused on improving market linkages as discussed in SAFM that support aggregated marketing or about building social capital to be used as collateral [67].

\section{Smart Agricultural Futures Market (SAFM)}

\subsection{Research Approach-Creating SAFM}

This research is carried out following design science research (DSR) methodology, a method of addressing salient unsolved problems in unique or innovative ways or solved problems in more effective or efficient ways [19]. While identifying and representing opportunities and problems in an actual environment is a good starting point in DSR [68], enhancing the environment with novel artifacts and the related process is the desire of design science research [69]. DSR consists of three cycles: relevance cycle (RC), design cycle (DC), and rigor cycle $(\mathrm{RgC})$. The relevance cycle focuses on problem understanding in the actual environment and evaluating the output in the application domain. The design cycle refers to generating design alternatives and evaluating them against the requirements until a satisfactory design is achieved. The rigor cycle provides the past knowledge for the selection and application of appropriate theories for constructing and evaluating the artifact [68].

Thus, the process of creating SAFM based on DSR methodology and the relevant cycles are illustrated in Figure 1.

The data-gathering in Figure 1 is one of the most important steps in creating SAFM, since it provided the understanding of the problem of the actual environment that led to developing the first artifact. In this step, we interviewed smallholder farmers from the central province in Sri Lanka, a developing country in the South Asian region, about their 
selling mechanisms [8]. We adopted scenario transformation methodology [70] to analyze the farmers' responses. We developed four different scenarios on selling mechanisms practiced by these farmers, derived claims for each scenario, identifying causal relationships. Then, each claim is further analyzed to obtain positive and negative consequences. [8]. These consequences led us to two major design moves [70] for a future system that maintain or even enhance the farmers' positive consequences while minimizing or eliminating the negative consequences [8]. The findings from the analysis, the design moves, and the mechanism used to address the findings are tabulated in Table 2.

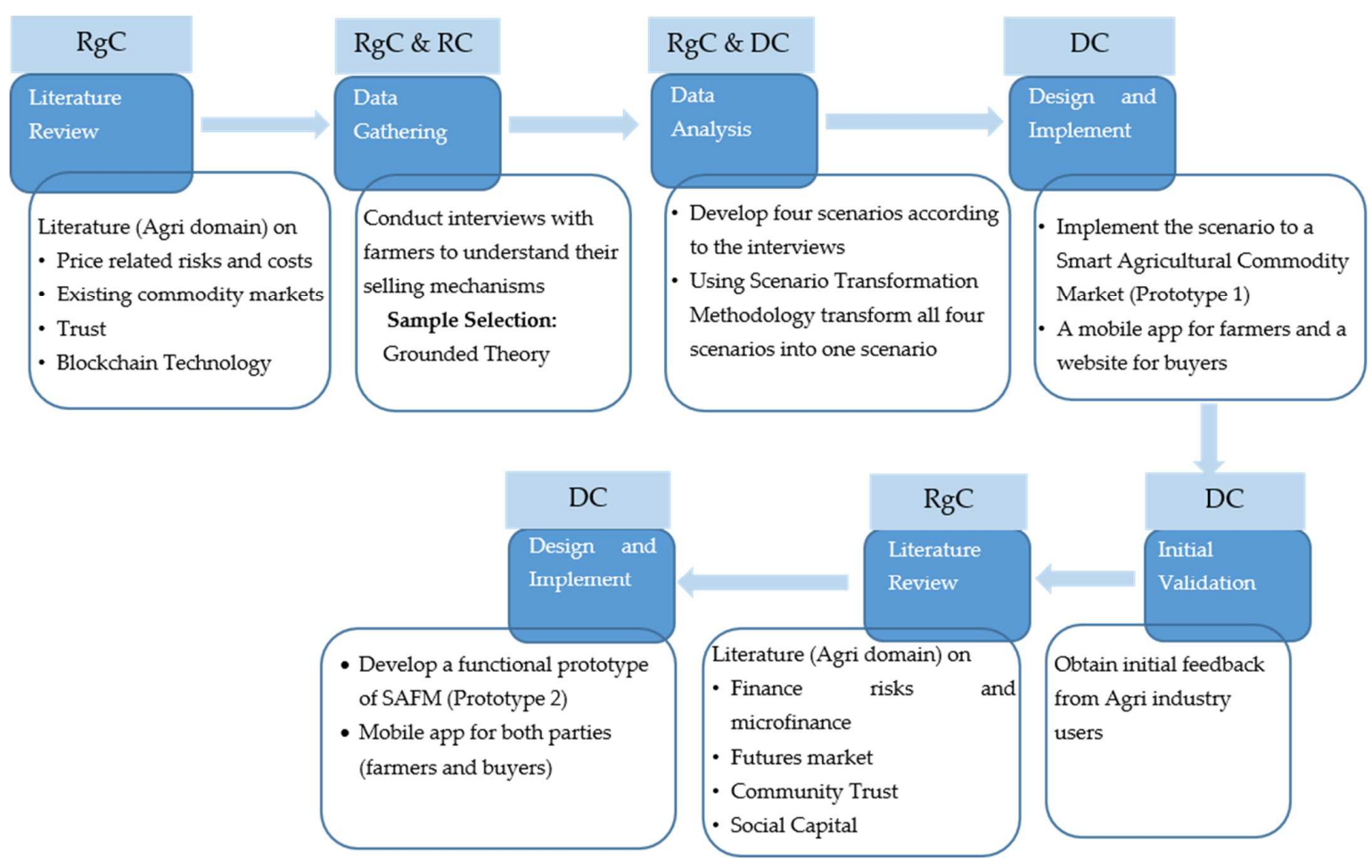

Figure 1. The Process of Creating SAFM.

Table 2. Findings, design moves, and the mechanisms used address the findings.

\begin{tabular}{|c|c|c|}
\hline Finding & Design Move & Mechanism \\
\hline $\begin{array}{l}\text { Farmers often choose a broker or buyer with } \\
\text { pre-established trust, although they receive } \\
\text { money } 2 / 3 \text { weeks later and the prices are low. } \\
\text { They sell to unknown brokers only if they } \\
\text { receive money on the spot due to the risk of } \\
\text { not getting paid since now there is no } \\
\text { pre-established trust. }\end{array}$ & $\begin{array}{l}\text { the system requires a mechanism to minimize } \\
\text { the risk of not getting paid and establish trust } \\
\text { between farmers and unknown brokers to } \\
\text { enable farmers to choose any broker who } \\
\text { offers comparative rates without relying on } \\
\text { known brokers }\end{array}$ & $\begin{array}{l}\text { Establishing contracts between farmers and } \\
\text { brokers in the form of smart contracts in a } \\
\text { blockchain platform to minimize the risk of } \\
\text { not getting paid, leading to trust } \\
\text { Integrating rating and ranking system-to } \\
\text { build online trust }\end{array}$ \\
\hline $\begin{array}{l}\text { The quantities produced by smallholder } \\
\text { farmers are little due to the small extent of the } \\
\text { farmlands. } \\
\text { Thus, the cumulative of both observable and } \\
\text { unobservable transaction costs can result in } \\
\text { lower margins for marginal and smallholder } \\
\text { farmers. }\end{array}$ & $\begin{array}{l}\text { the system requires a mechanism to support a } \\
\text { market linkage that facilitates aggregated } \\
\text { marketing for farmers to obtain better rates }\end{array}$ & $\begin{array}{l}\text { Integrating with the Digital Agribusiness } \\
\text { Ecosystem (DAE) since it has the capability of } \\
\text { predicting expected harvesting period and } \\
\text { expected harvest for each farmer for each crop } \\
\text { according to the season. } \\
\text { So, we can create farmer groups aggregating } \\
\text { harvest according to the geographical } \\
\text { proximity, crop type, and buyer's expected } \\
\text { buying period (expected harvesting period) }\end{array}$ \\
\hline
\end{tabular}

The design moves and the mechanisms used to address the negative consequences led us to derive the transformed scenario and develop the first prototype [8]. The prototype was presented to Agri industry experts to receive initial feedback. Based on their input and literature on agriculture-related risks, requirement derivation and the development 
of the second prototype was carried out. The changes from prototype 1 to prototype 2 is tabulated in Table 3. However, both prototypes are built based on the mechanisms used to address the findings from the interviews: aggregated marketing and establishing contracts in a blockchain platform as smart contracts to minimize the risk of not getting paid.

Table 3. Changes from Prototype1 to Prototype2.

\begin{tabular}{|c|c|}
\hline Prototype1 & Prototype2 (SAFM) \\
\hline $\begin{array}{l}\text { Facilitates only one form of exchange: deliver material early to } \\
\text { receive money later. }\end{array}$ & $\begin{array}{l}\text { Facilitates three forms of exchanges: deliver material to receive } \\
\text { money on the spot, deliver material early to receive money later, } \\
\text { and receive money early to deliver material later. }\end{array}$ \\
\hline Farmer pays $10 \%$ as collateral. & Farmer's social capital is used as collateral \\
\hline Farming community concept is not included. & $\begin{array}{l}\text { Blockchain-based farming communities are introduced and } \\
\text { ranks are assigned to the community. }\end{array}$ \\
\hline $\begin{array}{l}\text { Harvest is aggregated according to the geographical proximity, } \\
\text { crop type and expected harvesting period. }\end{array}$ & $\begin{array}{l}\text { Harvest is aggregated according to the farming community, } \\
\text { crop type, and expected harvesting period. }\end{array}$ \\
\hline Does not address buyer's quality concerns. & Addresses buyer's quality concerns. \\
\hline Does not support trading smart futures contracts. & Supports trading smart futures contracts. \\
\hline $\begin{array}{l}\text { Does not address any issues related to financial risks } \\
\text { (microfinance issues). }\end{array}$ & Addresses issues related to financial risks (microfinance issues). \\
\hline Tries to build trust via smart contracts enforcement. & Allows building trust gradually, forming sustainable system. \\
\hline
\end{tabular}

The SAFM was evaluated for its functional correctness as per the design cycle in DSR methodology. After evaluating the prototype1 following were identified as essential requirements for the artifact to be useful in a real environment by the experts. In the prototype 2 design, we have achieved all these requirements, as shown in Table 4.

Table 4. Requirements identified by the experts and functions that address the requirements.

\begin{tabular}{|c|c|c|}
\hline No & Requirements Identified by Experts & Feature in Prototype2 to Address these Requirements \\
\hline 1 & $\begin{array}{c}\text { Farmers will not willingly pay } 10 \% \text { of the agreed total amount as a } \\
\text { deposit. }\end{array}$ & $\begin{array}{l}\text { The concept of social capital is introduced, thus, farmers do not pay } \\
\text { a deposit. }\end{array}$ \\
\hline 2 & $\begin{array}{l}\text { The contract will be established while the crops are still growing, thus, } \\
\text { they should be able to check the quality of the product. }\end{array}$ & $\begin{array}{c}\text { farmers are enabled to upload photos, and community members } \\
\text { are enabled to certify their genuineness }\end{array}$ \\
\hline 3 & $\begin{array}{l}\text { Uploading photos of growing crops in certain stages to address the } \\
\text { quality concerns of buyer. }\end{array}$ & $\begin{array}{l}\text { As mentioned in raw } 2 \text {, farmers are enabled to upload photos, and } \\
\text { community members are enabled to certify their genuineness. }\end{array}$ \\
\hline 4 & Buyers would prefer a mobile app rather than a website. & Mobile app for buyers is designed. \\
\hline 5 & $\begin{array}{l}\text { Buyers would prefer if the app displayed both expected harvest and } \\
\text { ready lots of harvest. }\end{array}$ & $\begin{array}{c}\text { Facilitated farmers to advertise both existing harvest and expected } \\
\text { harvest in the mobile app. }\end{array}$ \\
\hline 6 & Buyers would prefer a map view or list view rather than a graph view. & Prototype 2 provides map view, list view and graph view. \\
\hline 7 & Buyers would prefer to see the current market prices in the bid form. & The bid form displays the current market price at the bottom. \\
\hline 8 & $\begin{array}{l}\text { farmers would prefer to see current market prices in the offer } \\
\text { acceptance form. }\end{array}$ & $\begin{array}{c}\text { Offer acceptance form displays the current market price at the } \\
\text { bottom. }\end{array}$ \\
\hline 9 & $\begin{array}{l}\text { Buyers would prefer to see the preferred districts and preferred crops in } \\
\text { a distinct format. }\end{array}$ & $\begin{array}{l}\text { Preferred districts are marked with different color and preferred } \\
\text { crops are given in a separate section in the UI. }\end{array}$ \\
\hline
\end{tabular}

Evaluating prototype 2 is planned to be done as part of the "Kisan Samruddhi" project conducted by Widya [71].

\subsection{Evolution of Trust in SAFM}

E.M. Rogers developed the Diffusion of Innovation (DOI) theory in 1962 [72], explaining how an innovation is adopted and spreads through a population or a social system. While the adoption does not happen simultaneously, it also depends on the characteristics of the people in the target domain. Thus, the adopters are divided into five categories [72] as follows.

1. Innovators: They are risk-takers and only need a little motivation to try the innovation first.

2. Early adopters: People who enjoy leadership roles and are comfortable trying innovations when manuals or information sheets are available. 
3. Early majority: They embrace new ideas before ordinary people do with success stories and evidence that innovation works.

4. Late majority: They will try only when the majority has adopted the innovation successfully.

5. Laggards: They are the most challenging group to adopt an innovation.

We apply this DOI theory in the proposed futures market to gradually establish and enhance trust between farmers and buyers in a stage-wise manner.

- $\quad$ Stage 1:

In the proposed futures market, the farming community is formed as a blockchainbased community where transactions between community members become untamperable, reliable, and transparent to all community members. Since reliable information influences trust automation [43], and blockchain's other inherent characteristics such as nonrepudiation, message authentication, and data integrity play a significant role in enabling trust, establishing a blockchain-based control mechanism for online exchanges can attract progressive farmers and progressive buyers to the system.

According to the DOI theory, these progressive farmers and buyers can regard as innovators. As they are risk-takers and only need a little motivation, this population can initiate the initial trust in the system (control mechanism).

\section{- $\quad$ Stage 2:}

When the progressive farmers and buyers enter the system, we facilitate them to commit exchanges as in a spot market where the material and cash are exchanged synchronously. The farmers can advertise their products under a special "Ready Lots" tab, and buyers can submit bids. Both parties can negotiate and agree on the crop type, quantity, grade, and price and then follow up with the harvest collection and payment transfer. The payment transfer can be carried out via the system. Therefore, the transactions are recorded in the blockchain. These records can be used to calculate ranks for farmers, buyers, and the community. Furthermore, all parties will be requested to rate their trading party for future use in generating ratings.

These established ranks and ratings have the potential to generate online trust between farmers and buyers. Facilitating trust establishment between farmers and buyers, targeting a trustworthy buyer-seller relationship can promote farmers' participation in markets [73]. Trust in the control mechanism and trust between trading parties can entice more farmers and buyers, the early adopters according to DOI theory, to the system, scaling it up and generating competition among the buyers.

\section{- Stage 3:}

The established trust enables farmers to advertise their expected harvest in the system, receive bids from buyers, negotiate and establish contracts between them as smart contracts in advance, securing a fixed price for their crop promptly. However, the conditions of the contracts are that buyer pays $10 \%$ of the total agreed amount to the system as a deposit to be stored in the system as a commitment to honoring the agreement, the farmer delivers the harvest according to the buyer's requirement after harvesting, and the buyer pays the balance $90 \%$ to the farmer via the system. The $10 \%$ deposit is also transferred to the farmer when the transaction is successful.

These successful transactions result in increasing ranks of farmers, buyers, and the community, leading to increased trust. By then, farmers will have established a strong social identity in their community that could be used as collateral in the form of social capital. The community brand reputation is also exhibited, enhancing the trust to facilitate trading futures contracts.

- $\quad$ Stage 4:

While facilitating trading futures contracts can entice more buyers with the probability of generating profit through futures contract trading, the presence of more buyers can attract 
more farmer communities to the system. This population can regard as the early majority according to DOI theory. Thus, the market platform will be scaled up, creating a stable market. The system can then introduce a modest system maintenance fee to be deducted from each transaction, effectuating a sustainable Smart Agricultural Futures Market.

Once the early majority adopts the proposed market, the late majority and the laggards will join since they can see the success.

This stage-wise evolution of trust emergence is depicted in Figure 2. It consists of two parts. While the left diagram explains the tasks required in the proposed market for trust establishment, including notes in the middle, the right diagram depicts the achieved outcome in each stage.

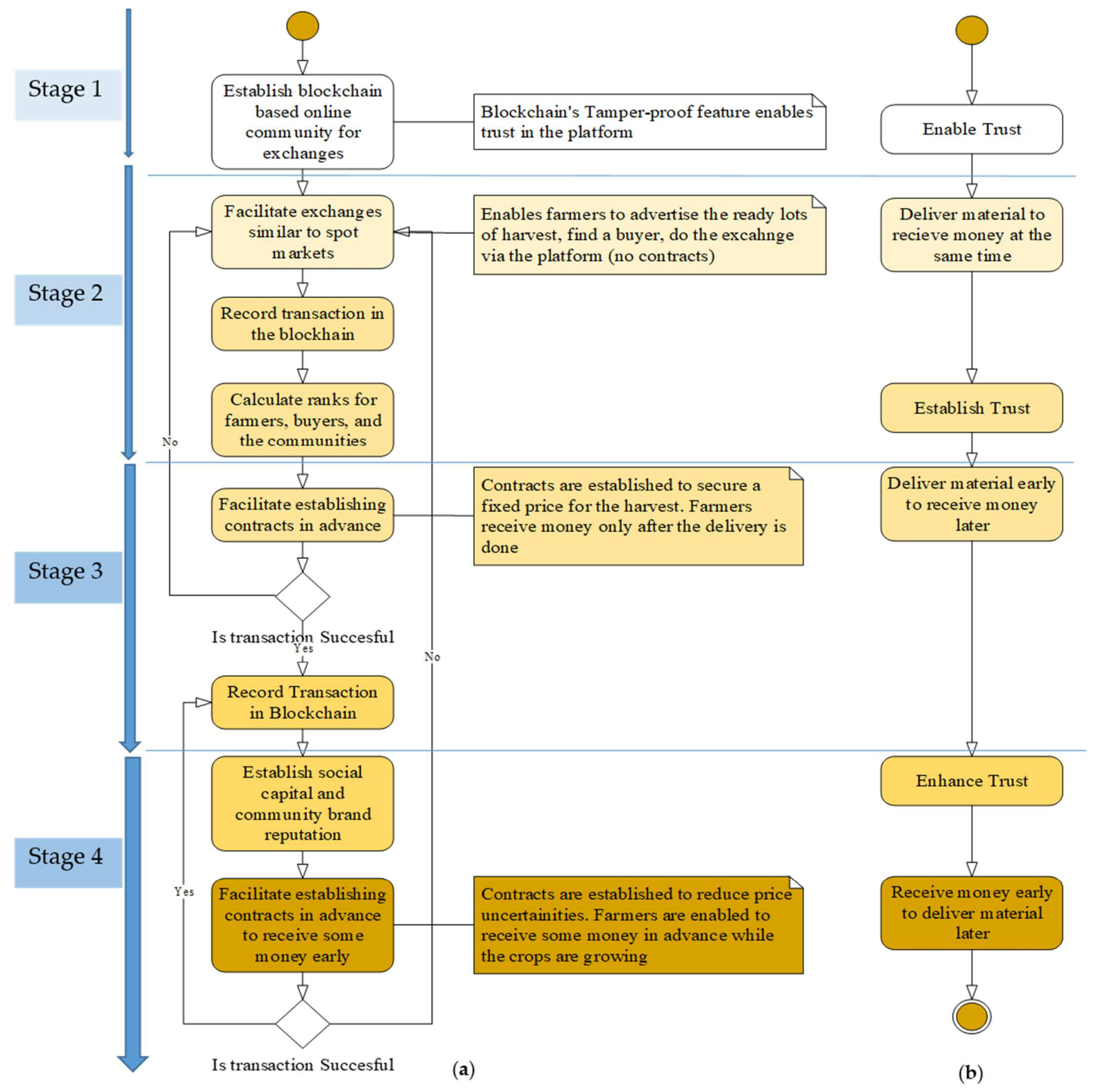

Figure 2. Activity diagrams on trust evolution in the proposed futures market. (a) Tasks required for trust establishment. (b) The achieved outcome in each stage. 


\subsection{SAFM}

SAFM consists of six components: a mobile app for farmers, a mobile app for buyers, the Digital Agrifood Ecosystem (DAE), a Contract Negotiator Module (CNM), the Blockchain Network, and a database as depicted in Figure 3.

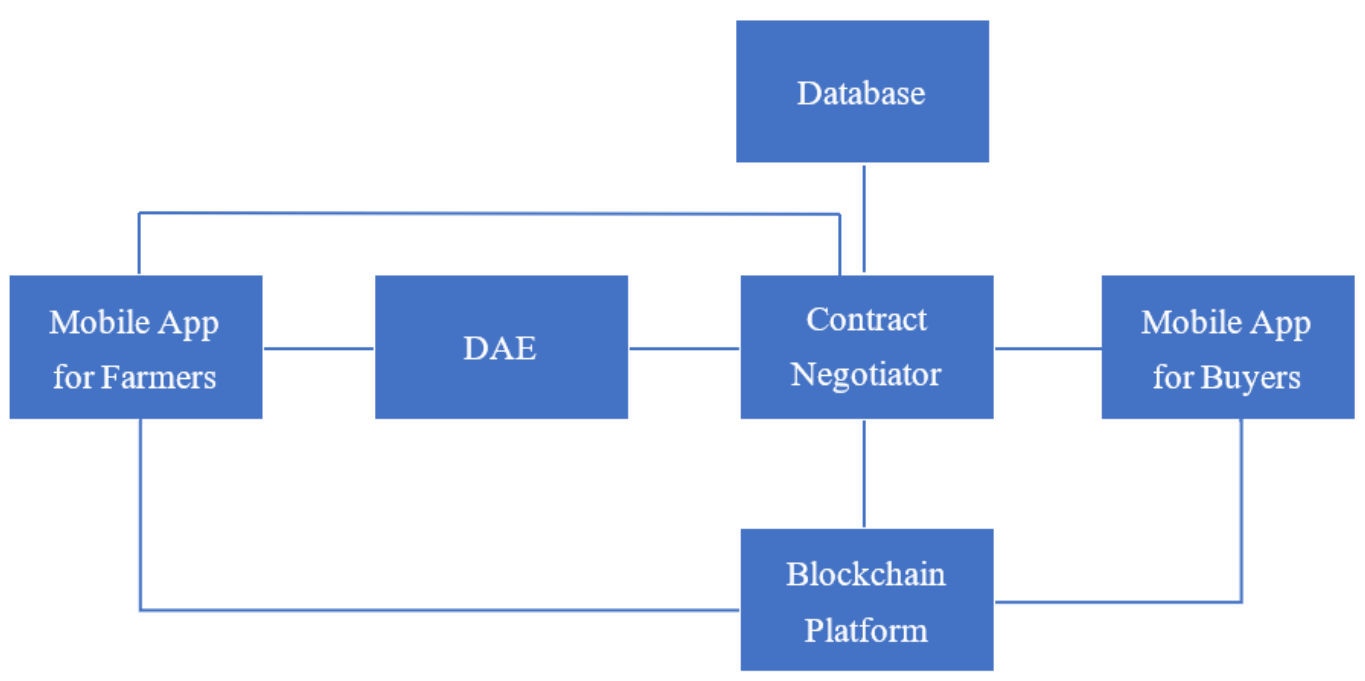

Figure 3. Conceptual model of SAFM.

\subsubsection{Digital Agrifood Ecosystem (DAE)}

DAE, previously known as Digital Knowledge Agribusiness Ecosystem (DKAE), consists of a database of quasi-static information about crops, pests and diseases, land preparation, and growing and harvesting methods according to the Package of Practices (PoP) for each crop. DAE provides this information to farmers as actionable information through mobile apps, enabling farmers to act upon the information he receives [74].

The farmer registers in DAE, providing his personal information, farmer community information, and farm information. Then the app lists the crops that can be grown in that location according to the agro-ecological zone. Then the farmer chooses the crops he expects to grow on that farm and enters the desired planting area and planting date for each crop. With this information, the app offers a detailed cost of cultivation for each crop and a crop calendar highlighting essential tasks that should be carried out to achieve optimum yield and manage pests and diseases better. Throughout the season, the farmer is notified to complete the tasks in the crop calendar [75]. When the tasks are completed, the farmer is requested to upload photos of growing crops to the system. The data points captured from the farmer and derived from DAE are tabulated in Table 5. DAE facilitates farmers to maintain a crop diary while empowering them to complete tasks with accurate information [76,77].

Table 5. Data points captured from the farmer and derived from DAE.

\begin{tabular}{cc}
\hline Data Point & Source \\
\hline Farmer's personal data and community data & Farmer \\
List of crops that can be grown on the farm & Farmer \\
List of crops farmer plans to grow & DAE \\
Farm extent for each crop & Farmer \\
Expected planting date for each crop & Farmer \\
Detailed cost of cultivation for each crop & Farmer \\
Crop calendar for each crop & DAE \\
Updates on tasks & DAE \\
Photos of growing crops & Farmer \\
Yield per unit for each crop according to season and location & Farmer \\
\hline
\end{tabular}


Thus, each farmer's expected production levels for each crop can be calculated using the farm extent and yield per acre according to season and location as specified in PoP. Furthermore, the expected harvesting period can be derived from the crop calendar and actual planting date.

\subsubsection{Contract Negotiator Module (CNM)}

The Contract Negotiator Module (CNM) is a server-side software module that maintains the coordination and communication between farmers and buyers. In addition to that, it requests all PoPs, farmer community data, and the crop cultivation data: cultivation_Id, crop_Name, variety, planting_Date, farm_location, farm_Extent, extent_Units, farmer_Id, pop_Id, and pop_Version from DAE and saves in the database. Since the PoPs consist of yield per land unit according to the season and location, CNM calculates the expected harvest for each crop for each farmer using the farm location, farm extent, and yield per acre according to the season. Furthermore, the expected harvesting period is derived from the crop calendar and planting date.

CNM aggregates the expected harvest of each farmer according to the crop type, geographical proximity (administrative divisions), and expected harvesting period and sends that data to the buyers' mobile app. CNM also aggregates the production levels according to the crop type, farmer community, and expected harvesting period at buyers' request. Thus, it engenders Many-one-Many market linkages between farmers and buyers since many farmers are grouped into one community which is exposed to many buyers through the buyers' mobile app.

\subsubsection{Mobile App for Buyers}

The mobile app for the buyers displays aggregated expected harvest levels. If the buyer is not registered in the system, he can only see the data aggregated at a higher granularity level. When the buyer registers in the system, he is asked to provide his personal data and select the administrative divisions where he prefers to buy the harvest and the preferred crop types, as depicted in Figure 4.

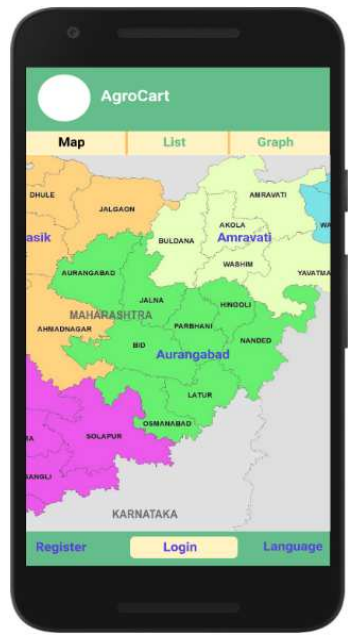

(a)

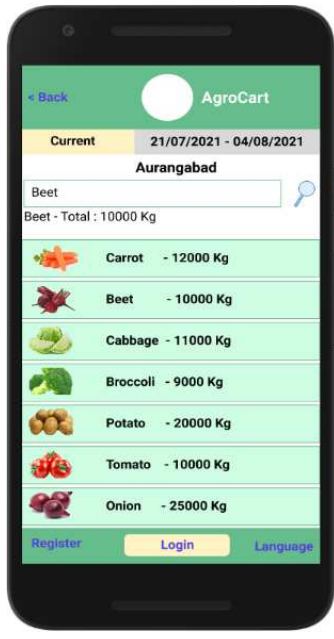

(b)

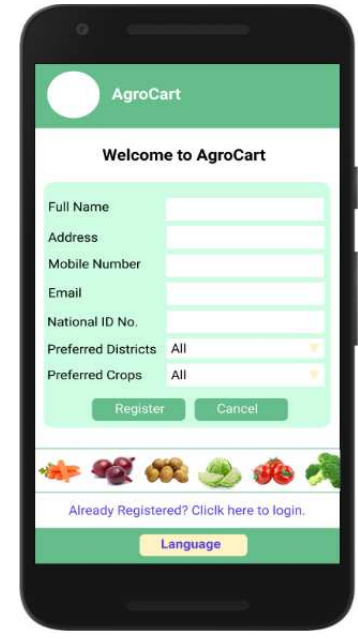

(c)

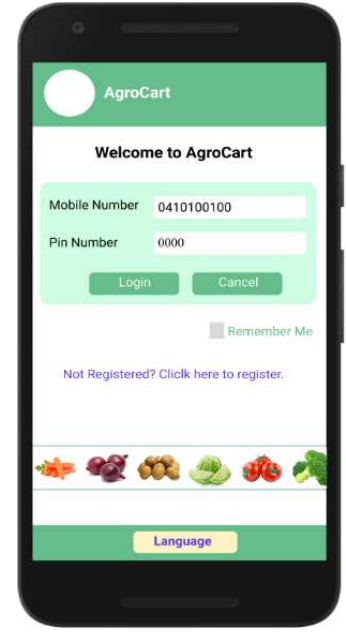

(d)

Figure 4. Mobile app UIs for the unregistered buyer. (a) Buyer views the map view. (b) Buyer taps on an administrative division name and sees the aggregated production levels in that division. (c) Buyer taps on the Register link to see the registration page. (d) Buyer taps on the Login button to see the Login page.

Once they register, the buyer can see both administrative division-wise and communitywise expected production levels. Since he has provided the preferred crop types and administrative divisions, the app distinctly displays them, facilitating the buyer to easily find this 
information. The buyer can navigate to the bidding form as illustrated in Figure 5, enter his requirements: crop, variety, grade, expected buying period, geographical location, farmers' community name, the quantity he hopes to buy, and the price he offers, and submit the bid to the system.

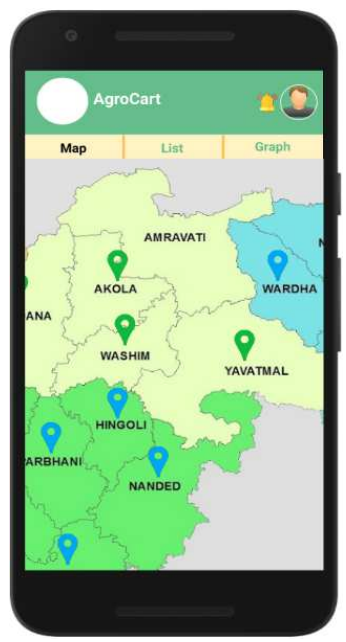

(a)

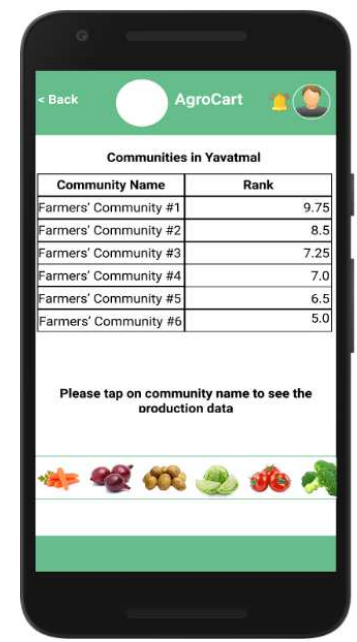

(b)

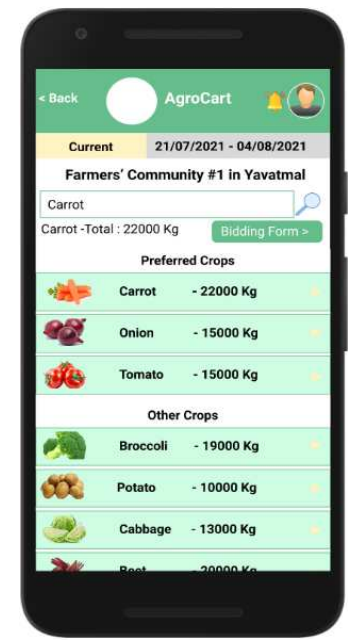

(c)

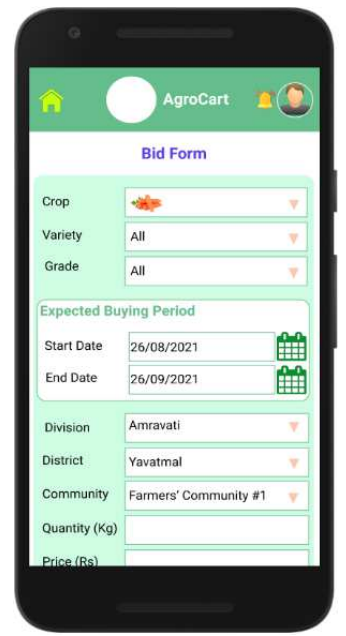

(d)

Figure 5. Mobile app UIs for the registered buyer until he submits a bid.(a) In the map view, buyer see their preferred locations as green markers. (b) By tapping on any marker, the buyer can see the communities and their ranks in the particular division. (c) The buyer can tap on the community name to see the production levels where preferred crops are separated from others. (d) Either tapping on "Bidding Form" or a crop, the buyer gets the bid form.

Once CNM receives the buyer's bid, it obtains the farmer id list for the chosen community, filters farmer ids according to the crop type, matches the expected buying period to the expected harvesting period, and sends the bid to the mobile apps for that list of farmers.

\subsubsection{Mobile App for Farmers}

The DAE has already been deployed in several locations to provide farmers with actionable information via mobile apps to guide their cultivation process [71]. Hence, a new module for the futures market can be integrated into one of these mobile apps. Thus, the farmer can tap on the futures market module to see the bids received. The bid includes crop type, expected quantity, expected harvesting period, offered price, and bid expiry date. There is a link for the farmer to check the buyer's rank for informed decision-making.

When the farmer receives a bid, as depicted in Figure 6, the app provides three options for the farmer to correspond as follows.

\section{Accept the offer;}

If the farmer is satisfied with the price offered by the buyer, the farmer can provide the quantity he expects to sell at that price in the offer acceptance form. If he desires to receive some money in advance when the contract is established, he can tick the checkbox, enter the percentage of the total amount he anticipates, and submit his acceptance. If he did not tick the checkbox, he would receive his payment once the harvest was delivered.

\section{Provide a counter offer;}

If the farmer anticipates selling his harvest at a higher price than the offered bid price, he can choose the second option to submit a counteroffer by entering the amount and his price. Like option one, he can choose to receive some money early or when the harvest is delivered to the buyer. 
The final option is to reject the offer and wait for another offer.

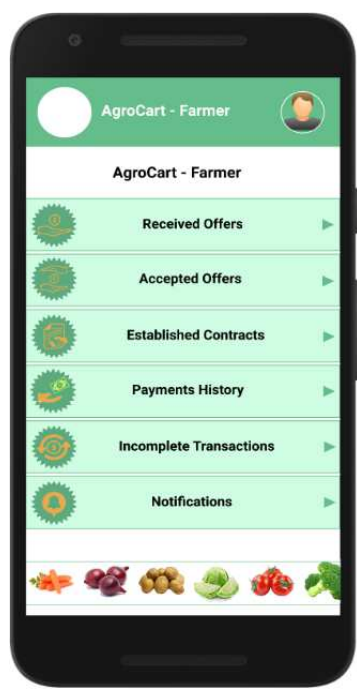

(a)

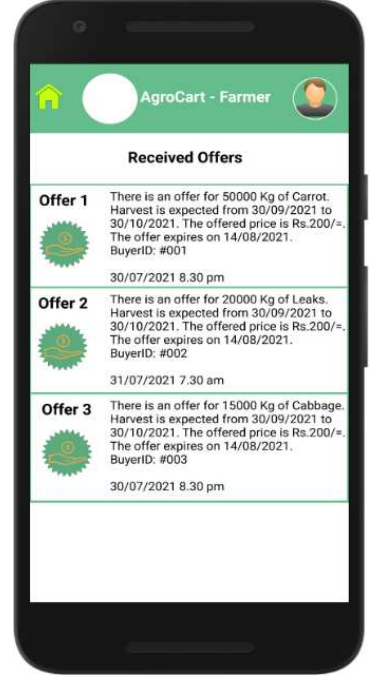

(b)

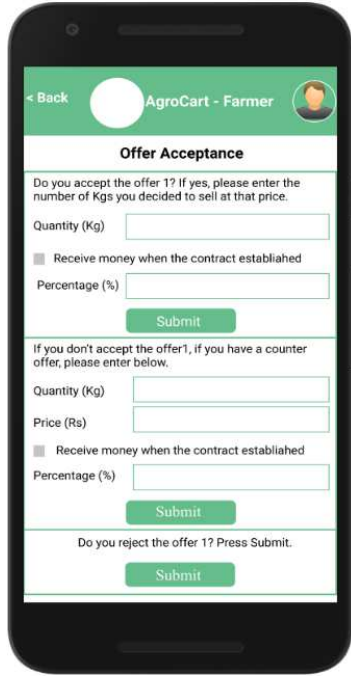

(c)

Figure 6. Mobile app UIs for thefarmer. (a) Futures market module home screen. (b) How farmer receives offers (c) Farmer's response form.

Farmers can either accept the offer, provide a counteroffer, or reject the offer until the bid expiry date. However, if other farmers who received the same bid accept the offer promptly and thus, the quantity required by the buyer is reached before the expiry date, the offer expires before the expiry date. Since they are trading contracts in advance while the crops are still growing on the farm, they are not forced to accept/reject the offers at once but empowered to contemplate their decision since there is a high possibility of receiving more bids from many other buyers. Other than that, the mobile app allows farmers to view the accepted offers, established contracts, payments history, incomplete transactions, and notifications.

However, farmers are not allowed to sell the total quantity of the expected harvest beforehand due to high risks encountered in the farming process. The permitted quantities for each farmer differ according to their ranks as follows.

- farmer's rank $\geq 9$ : can trade three-quarters of the expected harvest in advance;

- $5 \leq$ farmer's rank <9: can trade half of the anticipated harvest in advance;

- $\quad 3 \leq$ farmer's rank <5: can trade one-third of the expected harvest in advance;

- $1 \leq$ farmer's rank <3: can trade one-fourth of the anticipated harvest of advance.

Moreover, farmers are eligible to choose the option of receiving some money in advance only if their ranks are greater than nine. This constraint leads to risk mitigation not only for the farmer but also for the buyer since he is making upfront payments to the system expecting to purchase quality harvest.

Either when the bid expires or the quantity of the bid is reached, CNM analyses the farmers' responses against the buyer's requirement. This analysis can lead to one of the following criteria.

1. The total quantity of accepted offers = buyer's requirement (quantity)

If the total quantity of accepted offers matches the buyer's requirement, CNM sends a notification to the buyer's mobile app, including each farmer's id, the quantity he accepted, and whether the farmer anticipates some money early or not. The buyer can view each farmer's rank, the rank of the community he belongs to, and decide whether to continue establishing contracts or not.

1. The total quantity of accepted offers < buyer's requirement (quantity) 
If the total quantity of accepted offers is less than the buyer's requirement, CNM sends a notification to the buyer similar to the first criteria. If there are any counteroffers from farmers with higher prices, CNM includes them in the same notification. Thus, if the buyer needs to fulfill his requirement, he needs to accept the counteroffer price. If he agrees with the counteroffer price, all the farmers who received the same offer and accepted it receive the counteroffer price for their harvest.

In both situations, the buyer also can view the photos of growing crops and request validation of the genuineness of uploaded photos before making a decision, elucidating the quality concerns. The farmers are notified about the buyer's decision through the mobile app. Then CNM awaits the farmers' confirmation. Once the farmers' confirmation is received, CNM requests the buyer to transfer the required deposit to the platform. If the farmer chooses the option to receive some money in advance, entering a percentage, the buyer should pay that amount to the platform. Otherwise, the buyer should pay $10 \%$ of the total amount as an assurance of honoring the contract. CNM converts that fiat money into an equivalent amount of cryptocurrency. Then CNM sends a deploy message to the blockchain network with all required data: farmer id, farmer name, buyer id, buyer name, crop type, variety, grade, agreed price, agreed quantity, expected buying period, delivery location (most probably the farm-gate), price limit, contract type, and amount of cryptocurrency paid.

\subsubsection{Blockchain Platform}

Blockchain Platform records the transactions and facilitates the contract establishment between buyers and farmers. When it receives the deploy message from CNM with the required data, it deploys a new smart contract in the blockchain network. According to the farmers' consent, there will be two types of contracts established in the blockchain platform.

- A normal contract where farmer receives money when the harvest is collected by the buyer

When a normal contract is established between farmer and buyer, the buyer pays $10 \%$ of the total amount at the point of contract establishment. The amount of money is converted into cryptocurrency and recorded in the blockchain. The fiat money is held in the platform and will be released to the farmer when the material delivery is done.

- $\quad$ Futures contract where farmer receives some money in advance

If the farmer chooses to receive some money in advance, the contract is established as a futures contract. In that case, the buyer pays the percentage amount requested by the farmer at the point of establishing the contract. $10 \%$ of the total agreed amount is held in the system and recorded in the blockchain as the amount of cryptocurrency held. The balance is paid to the farmer. The balance of the total amount (total amount-percentage requested by the farmer) is recorded in the blockchain as payable to the farmer, and the buyer is instructed to pay it as installments after viewing the farmer's progress in his crop calendar.

During the expected harvesting period, CNM sends notifications to both the buyer and the farmers to check whether the harvest delivery is done and awaits a response. If the buyer has collected the harvest from the farmer, it sends an invoke message to execute the particular smart contract and release the amount of cryptocurrency. An equivalent amount of fiat money is transferred to the farmer's nominated account, either a bank account or mobile money account.

When the contract is established as a futures contract, the buyer can sell the futures contract to another buyer at a higher rate until the expected buying period, generating profits. He can either aggregate several futures contracts together and sell to a bigger buyer or disaggregate the futures contract into smaller ones and sell to different buyers as well. If he does that, CNM sends an invoke message to the blockchain platform to execute the 
smart contract early, and deploy a new contract between the farmer and the new buyer. The new buyer should continue paying the installments to the farmer.

\subsubsection{Database}

The database is used to store the data received from DAE, and all the data related to the exchanges occur between the farmer and buyer. When the transaction is successful, both parties are requested to provide feedback about their trading party as a rating, and that rating is also stored in the database. A farmer's or buyer's rank is calculated according to the successful transactions vs. all transactions stored in the database for the particular individual. The farmers' community's rank is calculated by averaging the community members' ranks stored in the database.

\section{Discussion}

For the majority of smallholder farmers in developing countries, the most accessible market is the informal market, where they receive less significant prices [6]. However, $80-90 \%$ of agricultural products are traded in such informal markets, including farm gate sales, roadside sales, village markets, rural assembly markets, and urban wholesale and retail market sales [2]. SAFM enables farmers to move beyond these informal markets to choose buyers who offer competitive prices while minimizing transaction-related risks by building both contractual and competence trust with the use of blockchain technology and smart contracts. As per Tan and Theon's generic trust model [22], SAFM has enabled transaction trust by facilitating party trust and control trust by alleviating the risks, inducing higher benefits.

SAFM is distinguished from other similar markets since it supports MoM market linkages between farmers and buyers, enabling community-wise aggregated marketing that has proven benefits for the farmers with access to bigger markets and reduced transaction costs. The increased bargaining power and aggregated quantities induce better price determination [6] for farmers' harvest.

Furthermore, the enhanced trust with social capital empowers farmers to sell a portion of their expected harvest to receive some money in advance to spend on the farming process, extricating the microfinance burden. Since the farmer obtains some cash while the crops are still in the growing stage, he is enabled to purchase Agri inputs in the right amounts to be applied at the right time for producing quality harvest at the optimal efficacy. Thus, reducing financial risks ushers improved revenue for farmers since quality harvest entices quality-oriented buyers who proffer competitive rates.

Negotiating and coordinating via SAFM contributes to a reduction in transaction costs for both the farmer and buyer. Since the buyer is collecting harvest at the farm-gate, he can accomplish it more efficiently by coordinating with all farmers who have agreed to sell at the particular time, reducing transportation costs significantly. Trading futures contracts facilitates the buyer to generate higher profits by re-selling them either after aggregating or disaggregating, resulting in the proposed futures market being more compelling to more buyers. It instigates decoupling material flow from the money flow, curtailing post-harvest wastage considerably since the harvest is collected or delivered to the final buyer from the farm-gate instead of transferring via several intermediaries. Since transferring the ownership of the futures contracts is recorded in the blockchain, SAFM also supports food traceability from the farm-gate to the final buyer.

As illustrated in Figure 1, SAFM is the second prototype of the series of implementation of the three cycles: RC, DC, and RgC in DSR methodology. Thus, it is an outcome of several iterations of literature reviews, data gathering through interviews among smallholder farmers in which the sample size is decided using Grounded Theory [78], developing scenarios, using scenario transformation methodology [70] to derive the transformed scenario, transforming the transformed scenario into a prototype, obtaining initial feedback about the prototypes from Agri industry experts, and design and implementation. While SAFM satisfies the original objective of empowering smallholder farmers to generate better 
revenue in the theoretical aspect, it should be evaluated in the context of utility and the contribution to the real environment and knowledge and the contribution to the knowledge base [68]. Thus, according to the Technology Readiness Level (TRL), which is used to assess the maturity of a technology [79], this research has reached TRL 3. TRL 3 is defined as "Analytical and experimental critical function and/or characteristic proof-of-concept" [79]. It is progressing towards TRL 4, in which laboratory level validation is performed.

\section{Future Research Directions}

Many developing nations have begun to experiment with blockchain technology and cryptocurrencies to implement local cryptocurrencies [80]. This trend increases the feasibility of the deployment of blockchain-based platforms such as SAFM, engendering benefits to impoverished farming communities to upgrade their livelihoods.

The social capital engendered due to farmers' engagement in SAFM can be used as collateral for purchasing Agri inputs as well. Thus, in future deployments, farmers can be facilitated to enter into contracts with Agri input suppliers, enabling farmers to pay the suppliers later once the harvest is sold or as installments. In addition, the purchasing of Agri inputs can also be performed in a similar approach as proposed in this research by aggregating the Agri input requirements community-wise to buy them at low rates, mitigating production risks.

Furthermore, since the $10 \%$ deposits made by the buyers are stored in the system, farmers can be facilitated to purchase insurance policies against production losses using that money, further alleviating production risks. Otherwise, insurance companies that already have implemented blockchain-based insurance policy systems $[80,81]$ can be integrated into the platform as new stakeholders.

\section{Conclusions}

This paper presents a novel approach to establish trust progressively that facilitates three modes of exchanges: deliver material to receive money on the spot, deliver material early to receive money later, and receive money early to deliver material later, facilitating online trust between farmers and buyers to evolve gradually. It is developed integrating several notions: community trust, social capital, aggregated marketing, and futures contracts. It mitigates market risks and financial risks encountered by the farmers while engendering future possibilities of alleviating production risks as well.

The approach is demonstrated as the Smart Agricultural Commodity Market platform, integrating a blockchain network to create a blockchain-based community, record all transactions and execute the smart contracts. The implementation and evaluation of this market platform and future enhancements will enable smallholder farmers to generate better income from their harvest while experiencing minimal financial constraints, extricating them from the vicious poverty trap.

Author Contributions: Conceptualization, M.K., R.N.C., and A.G.; methodology, M.K., R.N.C., and A.G.; software, M.K.; validation, M.K., R.N.C., and A.G.; formal analysis, M.K., R.N.C., and A.G.; investigation, M.K.; data curation, M.K.; writing-original draft preparation, M.K.; writing-review and editing, R.N.C. and A.G.; supervision, R.N.C. and A.G. All authors have read and agreed to the published version of the manuscript.

Funding: This research received no external funding.

Institutional Review Board Statement: Not applicable.

Informed Consent Statement: Informed consent was obtained from all subjects involved in the study.

Data Availability Statement: Not Applicable

Conflicts of Interest: The authors declare no conflict of interest. 


\section{References}

1. Wolfenson, K.D.M. Coping with the Food and Agriculture Challenge: Smallholders' Agenda; Food and Agriculture Organisation of the United Nations: Rome, Italy, 2013.

2. Ferris, S.; Robbins, P.; Best, R.; Seville, D.; Buxton, A.; Shriver, J.; Wei, E. Linking Smallholder Farmers to Markets and the Implications for Extension and Advisory Services; United States Agency for International Development: Washington, DC, USA, 2014.

3. Somashekhar, I.; Raju, J.; Patil, H. Agriculture Supply Chain Management: A Scenario in India. Res. J. Soc. Sci. Manag. 2014, 4, 89-99.

4. Mitra, S.; Mookherjee, D.; Torero, M.; Visaria, S. Asymmetric Information and Middleman Margins: An Experiment with Indian Potato Farmers. Rev. Econ. Stat. 2018, 100, 1-13. [CrossRef]

5. Hamangoda, I.; Pushpakumari, P. AgStat; Department of Agriculture: Peradeniya, Sri Lanka, 2020; Volume XVII.

6. Negi, D.S.; Birthal, P.S.; Roy, D.; Khan, M.T. Farmers' choice of market channels and producer prices in India: Role of transportation and communication networks. Food Policy 2018, 81, 106-121. [CrossRef]

7. Ranjan, R. Challenges to Farm Produce Marketing: A Model of Bargaining between Farmers and Middlemen under Risk. J. Agric. Resour. Econ. 2017, 42, 386-405.

8. Kumarathunga, M.; Calheiros, R.; Ginige, A. Technology-Enabled Online Aggregated Market for Smallholder Farmers to Obtain Enhanced Farm-gate Prices. In Proceedings of the International Research Conference in Smart Computing and Systems Engineering, Colombo, Sri Lanka, 16 September 2021.

9. Sako, M. Price, Quality and Trust: Inter-Firm Relations in Britain and Japan; Cambridge University Press: Cambridge, UK, 1992.

10. Bourdieu, P. The Forms of Capital; Routledge: Cambridge, UK, 2018.

11. Hull, J.; Treepongkaruna, S.; Colwell, D.; Heaney, R.; Pitt, D. Fundamentals of Futures and Options Markets; Pearson Higher Education AU: Melbourne, VIC, Australia, 2013.

12. Blank, S.C.; Carter, C.A.; McDonald, J. Is the market failing agricultural producers who wish to manage risks? Contemp. Econ. Policy 1997, 15, 103-112. [CrossRef]

13. Schaffnit-Chatterjee, C.; Schneider, S.; Peter, M.; Mayer, T. Risk management in agriculture. In Deutsche Bank Reseach; 2010. Available online: https:/ /www.farm-d.org/app/uploads/2019/05/Deutsche-Bank-Research-Risk-Management-in-Agriculture091710.pdf (accessed on 1 January 2022).

14. Dey, K.; Gandhi, V.P.; Debnath, K. Literature on Farmers' Participation in Futures. In Farmers' Participation in India's Futures Markets: Potential, Experience, and Constraints; Dey, K., Gandhi, V.P., Debnath, K., Eds.; Springer: Singapore, 2021 ; pp. $23-31$.

15. Meijerink, G.; Bulte, E.; Alemu, D. Formal institutions and social capital in value chains: The case of the Ethiopian Commodity Exchange. Food Policy 2014, 49, 1-12. [CrossRef]

16. Roy, D.; Thorat, A. Success in high value horticultural export markets for the small farmers: The case of Mahagrapes in India. World Dev. 2008, 36, 1874-1890. [CrossRef]

17. Fischer, E.; Qaim, M. Linking Smallholders to Markets: Determinants and Impacts of Farmer Collective Action in Kenya. World Dev. 2012, 40, 1255-1268. Available online: https://www.sciencedirect.com/science/article/abs/pii/S0305750X11003020 (accessed on 1 January 2022). [CrossRef]

18. Markelova, H.; Meinzen-Dick, R.; Hellin, J.; Dohrn, S. Collective action for smallholder market access. Food Policy 2009, 34, 1-7. [CrossRef]

19. Hevner, A.; Chatterjee, S. Design science research in information systems. In Design Research in Information Systems; Springer: Berlin/Heidelberg, Germany, 2010; pp. 9-22.

20. Mayer, R.C.; Davis, J.H.; Schoorman, F.D. An integrative model of organizational trust. Acad. Manag. Rev. 1995, 20, 709-734. [CrossRef]

21. Laeequddin, M.; Sahay, B.S.; Sahay, V.; Abdul Waheed, K. Trust building in supply chain partners relationship: An integrated conceptual model. J. Manag. Dev. 2012, 31, 550-564. [CrossRef]

22. Tan, Y.-H.; Thoen, W. Formal aspects of a generic model of trust for electronic commerce. Decis. Support Syst. 2002, 33, $233-246$. [CrossRef]

23. Bressler, S.E.; Grantham, C.; Grantham, C.E. Communities of Commerce; McGraw-Hill Trade: Blacklick, OH, USA, 2000.

24. Putnam, R.D. Making Democracy Work: Civic Traditions in Modern Italy; Princeton University Press: Princeton, NJ, USA, 1993.

25. Geleta, E.B.A. The Microfinance Mirage: The Politics of Poverty, Social Capital and Women's Empowerment in Ethiopia; Ashgate: Farnham, UK; Burlington, VT, USA, 2015.

26. Macaulay, L.A.; Keeling, K.; McGoldrick, P.; Dafoulas, G.; Kalaitzakis, E.; Keeling, D. Co-evolving e-tail and on-line communities: Conceptual framework. Int. J. Electron. Commer. 2007, 11, 53-77. [CrossRef]

27. Bagozzi, R.P.; Dholakia, U.M. Antecedents and purchase consequences of customer participation in small group brand communities. Int. J. Res. Mark. 2006, 23, 45-61. [CrossRef]

28. Bagozzi, R.P.; Dholakia, U.M. Intentional social action in virtual communities. J. Interact. Mark. 2002, 16, 2-21. [CrossRef]

29. Hsu, C.P.; Chiang, Y.F.; Huang, H.C. How experience-driven community identification generates trust and engagement. Online Inf. Rev. 2012, 36, 72-88. [CrossRef]

30. Di Pierro, M. What is the blockchain? Comput. Sci. Eng. 2017, 19, 92-95. [CrossRef]

31. Szabo, N. Smart Contracts. Available online: http://www.fon.hum.uva.nl/rob/Courses/InformationInSpeech/CDROM/ Literature/LOTwinterschool2006/szabo.best.vwh.net/smart.contracts.html (accessed on 24 July 2019). 
32. Kubac, L. RFID Technology and Blockchain in Supply Chain. In Transactions of the VŠB-Technical University of Ostrava, Mechanical Series; 2018; Volume LXIV. Available online: http:/ / transactions.fs.vsb.cz/2018-1/2042.pdf (accessed on 1 January 2022).

33. Alharby, M.; van Moorsel, A. Blockchain-based Smart Contracts: A Systematic Mapping Study. arXiv 2017, arXiv:1710.06372. [CrossRef]

34. Verma, A.; Garg, A. Blockchain: An Analysis on next-generation internet. Int. J. Adv. Res. Comput. Sci. 2017, 8, 429-432. [CrossRef]

35. Caro, M.P.; Ali, M.S.; Vecchio, M.; Giaffreda, R. Blockchain-based traceability in Agri-Food supply chain management: A practical implementation. In Proceedings of the IoT Vertical and Topical Summit on Agriculture-Tuscany (IOT Tuscany), Tuscany, Italy, 8-9 May 2018; pp. 1-4.

36. Mik, E. Smart contracts: Terminology, technical limitations and real world complexity. Law Innov. Technol. 2017, 9, 269-300. [CrossRef]

37. Xu, X.; Weber, I.; Staples, M.; Zhu, L.; Bosch, J.; Bass, L.; Pautasso, C.; Rimba, P. A taxonomy of blockchain-based systems for architecture design. In Proceedings of the 2017 IEEE International Conference on Software Architecture (ICSA), Gothenburg, Sweden, 3-7 April 2017; pp. 243-252.

38. Fang, W.; Chen, W.; Zhang, W.; Pei, J.; Gao, W.; Wang, G. Digital signature scheme for information non-repudiation in blockchain: A state of the art review. EURASIP J. Wirel. Commun. Netw. 2020, 2020, 56. [CrossRef]

39. Savelyev, A. Copyright in the blockchain era: Promises and challenges. Comput. Law Secur. Rev. 2018, 34, 550-561. [CrossRef]

40. Katz, J. Digital signatures: Background and definitions. In Digital Signatures; Springer: Berlin/Heidelberg, Germany, 2010; pp. 3-33.

41. Kim, J.-S.; Shin, N. The impact of blockchain technology application on supply chain partnership and performance. Sustainability 2019, 11, 6181. [CrossRef]

42. Kim, I.-H. The task and view of records and archives management reform-Governance of records and archives management. Korean J. Arch. Stud. 2005, 3-14. [CrossRef]

43. Kraus, J.M.; Forster, Y.; Hergeth, S.; Baumann, M. Two routes to trust calibration: Effects of reliability and brand information on trust in automation. Int. J. Mob. Hum. Comput. Interact. 2019, 11, 1-17. [CrossRef]

44. Komarek, A.M.; De Pinto, A.; Smith, V.H. A review of types of risks in agriculture: What we know and what we need to know. Agric. Syst. 2020, 178, 102738. [CrossRef]

45. Thompson, N.M.; Bir, C.; Widmar, N.J.O. Farmer perceptions of risk in 2017. Agribusiness 2019, 35, 182-199. [CrossRef]

46. Patrick, G.R.; Wilson, P.N.; Barry, P.J.; Boggess, W.G.; Young, D.L. Risk perceptions and management responses: Producergenerated hypotheses for risk modeling. J. Agric. Appl. Econ. 1985, 17, 231-238. [CrossRef]

47. Jose, H.D.; Valluru, R.S. Insights from the crop insurance reform act of 1994. Agribus. Int. J. 1997, 13, 587-598. [CrossRef]

48. Harwood, J.L. Managing Risk in Farming: Concepts, Research, and Analysis; US Department of Agriculture, ERS: Washington, DC, USA, 1999.

49. Meuwissen, M.P.; Huirne, R.; Hardaker, J. Risk and risk management: An empirical analysis of Dutch livestock farmers. Livest. Prod. Sci. 2001, 69, 43-53. [CrossRef]

50. Akcaoz, H.; Kizilay, H.; Ozcatalbas, O. Risk management strategies in dairy farming: A case study in Turkey. J. Anim. Vet. Adv. 2009, 8, 949-958.

51. Nadezda, J.; Dusan, M.; Stefania, M. Risk factors in the agriculture sector. Agric. Econ. 2017, 63, 247-258. [CrossRef]

52. Lemeilleur, S.; Codron, J.-M. Marketing cooperative vs. commission agent: The Turkish dilemma on the modern fresh fruit and vegetable market. Food Policy 2011, 36, 272-279. [CrossRef]

53. Jaffee, S.; Siegel, P.; Andrews, C. Rapid agricultural supply chain risk assessment: A conceptual framework. Agric. Rural. Dev. Discuss. Pap. 2010, 47, 1-64.

54. Guirkinger, C.; Boucher, S.R. Credit constraints and productivity in Peruvian agriculture. Agric. Econ. 2008, 39, 295-308. [CrossRef]

55. Zuberi, H.A. Production function, institutional credit and agricultural development in Pakistan. Pak. Dev. Rev. 1989, 28, 43-55. [CrossRef]

56. Bank, T.W. Sri Lanka Improving Access to Financial Services Selected Issues. Available online: http://documents1.worldbank. org/curated/en/432531468303077756/pdf/349580CE0white10to0Finance01PUBLIC1.pdf (accessed on 29 December 2020).

57. Colombage, S. The potential of using mobile money systems for enhancing financial inclusion in Sri Lanka. Sri Lanka J. Adv. Soc. Stud. 2012, 1, 1-24. [CrossRef]

58. Banerjee, S.B.; Jackson, L. Microfinance and the business of poverty reduction: Critical perspectives from rural Bangladesh. Hum. Relat. 2017, 70, 63-91. [CrossRef]

59. Hammill, A.; Matthew, R.; McCarter, E. Microfinance and Climate Change Adaptation. IDS Bull. 2008, 39, 113-122. [CrossRef]

60. Mersland, R.; Strøm, R.Ø. Microfinance: Costs, lending rates, and profitability. Handb. Key Glob. Financ. Mark. Inst. Infrastruct. 2012, 489-499. [CrossRef]

61. Sridhar, V. Why do farmers commit suicide? The case of Andhra Pradesh. Econ. Political Wkly. 2006, 41, $1559-1565$.

62. Hundreds of Suicides in India Linked to Microfinance Organizations; Associated Press: New York, NY, USA, 2012. Available online: https:/ / www.businessinsider.com/hundreds-of-suicides-in-india-linked-to-microfinance-organizations-2012-2? $\mathrm{r}=\mathrm{AU}$ \& $\mathrm{IR}=\mathrm{T}$ (accessed on 1 January 2022). 
63. Wipulasena, A. Debt Drives Women to Suicide in North and East. Sunday Observer, 17 March 2019. Available online: https: //www.sundayobserver.1k/2019/03/17/news-features/debt-drives-women-suicide-north-and-east (accessed on 1 January 2022).

64. The Bangladesh Poor Selling Organs to Pay Debts. BBC, 28 October 2013. Available online: https://www.bbc.com/news/worldasia-24128096 (accessed on 1 January 2022).

65. Melik, J. Microcredit 'Death Trap' for Bangladesh's Poor. BBC, 3 November 2010. Available online: https://www.bbc.com/news / business-11664632 (accessed on 1 January 2022).

66. Liao, C.-H.; Lin, H.-E.; Yuan, S.-M. Blockchain-Enabled Integrated Market Platform for Contract Production. IEEE Access 2020, 8 , 211007-211027. [CrossRef]

67. Paul, S.; Joy, J.I.; Sarker, S.; Ahmed, S.; Das, A.K. An Unorthodox Way of Farming without Intermediaries Through Blockchain. In Proceedings of the 2019 International Conference on Sustainable Technologies for Industry 4.0 (STI), Dhaka, Bangladesh, 24-25 December 2019; pp. 1-6.

68. Hevner, A.R. A three cycle view of design science research. Scand. J. Inf. Syst. 2007, 19, 4.

69. Simon, H.A. The Sciences of the Artificial; MIT Press: Cambridge, MA, USA, 2019.

70. Rosson, M.B.; Carroll, J.M. Scenario based design. In Human-Computer Interaction; CRC Press: Boca Raton, FL, USA, 2009; pp. 145-162.

71. Widya. Available online: https://widya.io/ (accessed on 22 February 2022).

72. Rogers, E.M.A. Diffusion of Innovations, 5th ed.; Free Press: New York, NY, USA, 2003.

73. Lu, H.; Trienekens, J.H.; Omta, S.W.F.; Feng, S. Influence of guanxi, trust and farmer-specific factors on participation in emerging vegetable markets in China. NJAS Wagening. J. Life Sci. 2008, 56, 21-38. [CrossRef]

74. Ginige, A.; Walisadeera, A.I.; Ginige, T.; De Silva, L.; Di Giovanni, P.; Mathai, M.; Goonetillake, J.; Wikramanayake, G.; Vitiello, G.; Sebillo, M.; et al. Digital Knowledge Ecosystem for Achieving Sustainable Agriculture Production: A Case Study from Sri Lanka. In Proceedings of the 3rd IEEE International Conference on Data Science and Advanced Analytics, Montreal, QC, Canada, 17-19 October 2016; pp. 602-611.

75. Ginige, A.; Sivagnanasundaram, J. Enhancing Agricultural Sustainability through Crowdsensing: A Smart Computing Approach. J. Adv. Agric. Technol. 2019, 6, 161-165. [CrossRef]

76. Ginige, A. Digital knowledge ecosystems: Empowering users through context specific actionable information. In Proceedings of the 10th IADIS Multi Conference on Computer Science and Information Systems, Funchal, Portugal, 1-4 July 2016 ; pp. 57-65.

77. Ginige, T.; Richards, D.; Ginige, A.; Hitchens, M. Design for empowerment: Empowering Sri Lankan farmers through mobilebased information system. Commun. Assoc. Inf. Syst. 2020, 46, 19. [CrossRef]

78. Strauss, A.; Corbin, J. Basics of Qualitative Research Techniques: Techniques and procedures for developing grounded theory, 2nd ed.; Sage Publications; Citeseer: Thousand Oaks, CA, USA, 1998.

79. Tomaschek, K.; Olechowski, A.; Eppinger, S.; Joglekar, N. A survey of technology readiness level users. INCOSE Int. Symp. 2016, 26, 2101-2117. [CrossRef]

80. Forkast. Central and Southeast Asia among Fastest-Growing Regions in Global Crypto Adoption: Chainalysis. Available online: https:/ / forkast.news / central-southeast-asia-fastest-growing-regions-cryptocurrency/ (accessed on 31 January 2022).

81. AON. Aon, Oxfam, and Etherisc Launch First Blockchain-Based Agricultural Insurance Policies for Smallholder Farmers in Sri Lanka. Available online: https:/ /aon.mediaroom.com/2019-07-01-Aon-Oxfam-and-Etherisc-launch-first-blockchain-basedagricultural-insurance-policies-for-smallholder-farmers-in-Sri-Lanka (accessed on 31 January 2021). 